\title{
Perspective of Digital Intelligence Transformation: An Innovative Research on Integration and Training System of Accounting Talents with Characteristics in Oil and Gas Industry
}

\author{
Ruirui Fang, Lin Wang* \\ China University of Petroleum (Beijing) at Karamay, P.R. China \\ ${ }^{*}$ Corresponding author. Email:wlfj2004@126.com
}

\begin{abstract}
Digital intelligence technology represented by big data and artificial intelligence has led to tremendous changes in the accounting business and accounting professional environment, which has put forward new requirements for the transformation and innovation of accounting higher education. This paper is guided by the goal of student ability training, with the characteristics of the oil and gas industry, and the use of digital intelligence technology as a means to discuss from four aspects: reconstruction of training programs, modularization of curriculum, integration of faculty and integration of teaching models. It establisheds an innovative training system for accounting application-oriented talents under the background of interdisciplinary cross-discipline, and providees useful enlightenment for the innovative research and practice of promoting the cultivation of outstanding accounting talents in the digital economy era.
\end{abstract}

Keywords: Digital Intelligence Technology, Oil and Gas Industry, Accounting Talents, Training System.

\section{INTRODUCTION}

Digital intelligence technology has become the core driving force of global social development. Big data, artificial intelligence, cloud computing, Internet of Things, block-chain and other digital intelligence technologies and methods have become important strategic empowerment leading the transformation of the oil and gas industry. While the rapid changes in information technology are reconstructing the global economy, they have also fundamentally reshaped the structure of human capital factors, economic formats, and business models. The changes of the times will have a profound impact on the accounting theory functions and the development of the accounting profession. Therefore, how to adapt to the trend and requirements of the digital and intellectual transformation of the social economic environment and corporate business models, and to explore and practice the innovation and reconstruction of the undergraduate accounting professional training system has become a new direction and new topic for higher education innovation research in the new era.

\section{LITERATURE REVIEW}

Entering the era of "digital intelligence", science and technology have become the "first accounting environmental factor". Due to the upgrading of technical elements, the new market structure has produced major changes in the supply of accounting talents and has also presented greater opportunities and challenges for the reform of accounting education [1]. The transformation and further development of accountants under the background of "Internet +" has received extensive attention from academia and practical fields. In response to the impact of emerging technologies represented by "big, smart, mobile, cloud, and things", from 2016 to 2018, the Ministry of Finance of China successively issued the 13th Five-Year Plan for Accounting Reform and Development and a series of guidance documents, clearly requiring accounting to focus on the "integration of industry and finance", and the transformation of accounting talents from accounting to management [2]. However, the current mismatch between supply and demand in the accounting talent market is still serious. Although accounting personnel are increasingly using information technology and big data analysis, they still cannot meet the needs of business. Therefore, the 
technical and data analysis capabilities of accounting students should be improved, which is the focus of the discussion [3]. The biggest challenge facing accounting education in the era of artificial intelligence is not the new technology itself, but the ability of teachers to adopt the new technology [4]. Liu Yongze [5] points out that education is the key for the purpose of transforming accounting. The development of technology and the transformation of accounting call for the reform of accounting education. In 2019, China's six ministries and commissions issued the National Pilot Implementation Plan for the Construction of Integration of Industry and Education, clearly pointing out that it is necessary to deepen the integration of industry and education, and promote the organic connection of the education chain, the talent chain, the industrial chain, and the innovation chain [6]. Sledgianowski et al. [7] propose that curriculum integration of existing teaching resources and technology can help achieve the goal of talent training. Zhou Shouliang [8] proposes that the starting point for the reform of accounting education is to change the concept and goal of talent training, followed by clarifying the knowledge, ability and quality structure, and then reconstructing and recreating the course content and teaching mode. Zhou Jianping et al. [9] summarize the "Internet + Accounting" curriculum system construction experience, and reconstruct the accounting industryeducation integration curriculum system. Wei Juan [10] believes that the current problems of interdisciplinary accounting for undergraduate education are mainly the lack of interdisciplinary teaching teams and the existing teaching design is not conducive to the integration and application of interdisciplinary knowledge. Accounting interdisciplinary education needs to promote knowledge in different disciplines. The "two-dimensional" fusion between theory and practice.

After 5 years' continuous follow-up survey on the accounting professional training programs of 12 Chinese universities with a background in the oil and gas industry, it is found that currently in such universities, the undergraduate accounting professional training system basically adopts the "accounting + oil and gas" training system. The "industry financial module + basic information technology" training model has failed to form a new accounting application-oriented talent training system that meets the needs of the oil and gas industry for digital and intelligent transformation. Therefore, based on the characteristics of the oil and gas industry and the requirements of industry-financial integration, exploring the reconstruction of a threedimensional integrated talent training and innovation system of "accounting + oil and gas business + digital intelligence technology" under the accounting career orientation will be helpful for promoting the innovative development of higher education in industry Important practical significance.
Therefore, this paper will focus on three questions. Firstly, oriented by the goal of cultivating students' ability and corresponding to the logic of the new training system for three-dimensional integrated accounting talents, it is planned to build a course system of "Accounting Theory and Practice Course Module + Oil and Gas Extraction Business Course Module + Digital Intelligence Technology Application Course Module" under the modular structure so as to actually solve the problem of how to organically integrate courses under cross-disciplines, and avoid the phenomenon of "two skins" in teaching. Secondly, the issue of planning to solve problems such as the path and method of cultivating a blended teacher team will be discussed. The blended teacher team includes accounting professional teachers, oil and gas subject professional teachers, digital intelligence technology professional teachers and oil and gas industry practice experts. It is expected to form a teacher team with the characteristics of subject integration, cross-industry integration, and integration of industry, education and research. Lastly, "visualized oil and gas accounting big data analysis and decisionmaking virtual simulation teaching platform" can be built by fully relying on the university's location in a regional national energy base, and uniting with super-large oil and gas companies, high-level head information technology companies and other units. The problem of virtual teaching in the complex economic business of the industry can be solved by the online and offline blended teaching platform for accounting professional practice. It can also solve the problem of innovation in the teaching mode of industry-specific talents under the deep integration of industry, education and research.

\section{INNOVATIVE RESEARCH ON INTEGRATED TRAINING SYSTEMS OF ACCOUNTING TALENTS}

In order to focus on the new needs of social change and condense the characteristics of accounting professional training, a training system should be built in accordance with the requirements of accounting talents in the era of digital intelligence. In the training system, teachers' training can be regarded as the key to cultivating students' accounting professional judgment ability. The cross-integrated course module of "accounting theory and practice + oil and gas extraction business + digital intelligence technology application" will be systematically constructed based on the cultivation of students' industry-financial integration ability, digital intelligence targeting technical application ability and interdisciplinary thinking ability. The university can also cooperate with enterprises to build a virtual simulation teaching platform for digital intelligence oil and gas accounting specialty. 


\subsection{Reconstruction of A New Training System of Three-dimensional Integration of Accounting}

In the direction of training, it is guided by the theoretical system of social sciences, emphasizing the integration of local awareness and international perspective. In terms of training mode, it adapts to the changes of the era of big data and artificial intelligence technology, and forms the professional, digital and intelligent training system of accounting talents in crossintegration of oil and gas. In terms of training characteristics, a virtual teaching platform for digital intelligence oil and gas characteristic accounting should be built to adapt to the new needs triggered by the application of digital intelligence technology in the oil and gas industry. The accounting professional training system and program elements mainly include training objectives, graduation requirements, main subjects, professional core courses, academic system and degree awarded, graduation qualification standards and credit requirements, etc. In each training link, the applicationoriented talent training goals should always be adhered to so that the core training elements are logically matched with the training goals (Table 1).

\subsection{Constructing An Ability-oriented "Three- dimensional Four” Curriculum System}

Oriented by the cultivation of accounting professional talents, a "three-dimensional" integrated curriculum system is formed, that is, three curriculum dimensions of accounting theory and practice curriculum module, oil and gas extraction business curriculum module, and digital intelligence technology curriculum module, oil and gas extraction business curriculum module, and digital intelligence technology application curriculum module are constructed to achieve accounting application-oriented talents in a gradient manner. The "four" abilities cultivated are accounting professional judgment ability, oil and gas enterprise industry-financial integration ability, digital intelligence technology application ability and discipline integration thinking ability. The core curriculum system structure oriented by competency goals is as follows (Table 2).

Table 1. Achievement Matrix of Accounting Talent Cultivation Goals

\begin{tabular}{|c|c|c|c|c|c|c|c|}
\hline \multirow{6}{*}{$\begin{array}{l}\text { Teachi } \\
\text { ng and } \\
\text { practice }\end{array}$} & & \multicolumn{3}{|c|}{ Cross-integrated course modules } & \multirow[b]{2}{*}{$\begin{array}{l}\text { Compre } \\
\text { hensive } \\
\text { quality }\end{array}$} & \multirow[b]{2}{*}{$\begin{array}{l}\text { Internship } \\
\text { practice } \\
\text { link }\end{array}$} & \multirow[b]{2}{*}{$\begin{array}{l}\text { Degree } \\
\text { thesis } \\
\text { research }\end{array}$} \\
\hline & $\begin{array}{l}\text { Cultivating } \\
\text { system }\end{array}$ & $\begin{array}{l}\text { Accountin } \\
\text { g Theory } \\
\text { and } \\
\text { Practical } \\
\text { course } \\
\text { module }\end{array}$ & $\begin{array}{l}\text { Oil and Gas } \\
\text { Extraction } \\
\text { Business } \\
\text { Course } \\
\text { Module }\end{array}$ & $\begin{array}{c}\text { Digital } \\
\text { Intelligence } \\
\text { Technology } \\
\text { Application } \\
\text { Course Module }\end{array}$ & & & \\
\hline & Teachers & \multicolumn{3}{|c|}{ Cultivate an integrated teacher team } & & & \\
\hline & $\begin{array}{l}\text { Teaching } \\
\text { style }\end{array}$ & \multicolumn{3}{|c|}{$\begin{array}{l}\text { Diversified teaching methods based on case } \\
\text { teaching }\end{array}$} & & & \\
\hline & $\begin{array}{c}\text { Teaching } \\
\text { management }\end{array}$ & \multicolumn{3}{|c|}{$\begin{array}{l}\text { Institutionalized management throughout } \\
\text { the process }\end{array}$} & & & \\
\hline & Practice & \multicolumn{3}{|c|}{$\begin{array}{l}\text { “Three-tier and four-person” practice and } \\
\text { practice base; Visualized oil and gas } \\
\text { accounting big data analysis and decision- } \\
\text { making virtual teaching platform }\end{array}$} & & & \\
\hline \multirow{3}{*}{$\begin{array}{l}\text { The } \\
\text { second } \\
\text { classro } \\
\text { om }\end{array}$} & $\begin{array}{l}\text { Students } \\
\text { seminar }\end{array}$ & \multicolumn{5}{|c|}{$\begin{array}{l}\text { Continue to host high-level academic forums for international and } \\
\text { domestic students }\end{array}$} & \\
\hline & $\begin{array}{l}\text { Academic } \\
\text { activities }\end{array}$ & \multicolumn{5}{|c|}{$\begin{array}{l}\text { Academic lectures, professional conferences, case competitions, } \\
\text { outreach training, etc. }\end{array}$} & \\
\hline & $\begin{array}{l}\text { International } \\
\text { exchange }\end{array}$ & \multicolumn{5}{|c|}{ Organize multi-form and serialized international exchange activities } & \\
\hline \multirow{2}{*}{$\begin{array}{l}\text { Degree } \\
\text { thesis } \\
\text { researc } \\
\mathrm{h}\end{array}$} & $\begin{array}{l}\text { Supervisor } \\
\text { allocation }\end{array}$ & & & & \multicolumn{3}{|c|}{ Dual supervisor system } \\
\hline & $\begin{array}{l}\text { Quality } \\
\text { assurance }\end{array}$ & & & & \multicolumn{3}{|c|}{$\begin{array}{l}\text { Undergraduate thesis quality control } \\
\text { system }\end{array}$} \\
\hline
\end{tabular}


Table 2. Competence-based core curriculum system framework

\begin{tabular}{|c|c|c|c|c|c|}
\hline \multirow[b]{2}{*}{$\begin{array}{l}\text { Course } \\
\text { Type }\end{array}$} & \multirow[b]{2}{*}{ Course name } & \multicolumn{4}{|c|}{ Ability requirements to achieve training goals } \\
\hline & & $\begin{array}{l}\text { Accounting } \\
\text { profession } \\
\text { judgment } \\
\text { capability }\end{array}$ & $\begin{array}{l}\text { Oil and } \\
\text { gas } \\
\text { industry } \\
\text { financial } \\
\text { integration } \\
\text { capability }\end{array}$ & $\begin{array}{l}\text { Digital Intelligence } \\
\text { Technology } \\
\text { Application Ability } \\
\text { Volume up content } \\
\text { copy share }\end{array}$ & $\begin{array}{l}\text { Disciplin } \\
\text { ary } \\
\text { integrati } \\
\text { on } \\
\text { thinking } \\
\text { ability }\end{array}$ \\
\hline \multirow{11}{*}{$\begin{array}{l}\text { Accounti } \\
\text { ng } \\
\text { Theory } \\
\text { and } \\
\text { Practice } \\
\text { Course } \\
\text { Module }\end{array}$} & Principles of Accounting & $\sqrt{ }$ & & & \\
\hline & Intermediate Financial Accounting & $\sqrt{ }$ & & & \\
\hline & Cost and management accounting & $\sqrt{ }$ & $\sqrt{ }$ & & \\
\hline & Advanced Financial Accounting & $\sqrt{ }$ & $\sqrt{ }$ & & \\
\hline & Auditing & $\sqrt{ }$ & $\sqrt{ }$ & & $\sqrt{ }$ \\
\hline & Accounting Information System & $\sqrt{ }$ & & $\sqrt{ }$ & $\sqrt{ }$ \\
\hline & Financial Management & $\sqrt{ }$ & $\sqrt{ }$ & & $\sqrt{ }$ \\
\hline & Financial Report Analysis & $\sqrt{ }$ & $\sqrt{ }$ & $\sqrt{ }$ & $\sqrt{ }$ \\
\hline & Accounting Professional Ethics & $\sqrt{ }$ & $\sqrt{ }$ & & $\sqrt{ }$ \\
\hline & Oil and gas accounting & $\sqrt{ }$ & $\sqrt{ }$ & $\sqrt{ }$ & $\sqrt{ }$ \\
\hline & Control mechanism and internal & $\sqrt{ }$ & $\sqrt{ }$ & $\sqrt{ }$ & $\sqrt{ }$ \\
\hline \multirow{5}{*}{$\begin{array}{l}\text { Oil and } \\
\text { Gas } \\
\text { Extractio } \\
\mathrm{n} \\
\text { Business } \\
\text { Course } \\
\text { Module }\end{array}$} & Introduction to Petroleum Science & $\sqrt{ }$ & $\sqrt{ }$ & & $\sqrt{ }$ \\
\hline & Introduction to Petroleum Geology & $\sqrt{ }$ & $\sqrt{ }$ & & $\sqrt{ }$ \\
\hline & $\begin{array}{l}\text { Introduction to Prospecting } \\
\text { Technology and Engineering }\end{array}$ & $\sqrt{ }$ & $\sqrt{ }$ & & $\sqrt{ }$ \\
\hline & Introduction to Oil Production & $\sqrt{ }$ & $\sqrt{ }$ & & $\sqrt{ }$ \\
\hline & $\begin{array}{l}\text { Introduction to Digital Intelligence in } \\
\text { the Oil and Gas Industry }\end{array}$ & $\sqrt{ }$ & $\sqrt{ }$ & $\sqrt{ }$ & $\sqrt{ }$ \\
\hline \multirow{5}{*}{$\begin{array}{c}\text { Digital } \\
\text { Intelligen } \\
\text { ce } \\
\text { Technolo } \\
\text { gy } \\
\text { Applicati } \\
\text { on } \\
\text { Course } \\
\text { Module }\end{array}$} & Principles of Big Data Technology & & & $\sqrt{ }$ & $\sqrt{ }$ \\
\hline & Al Principles & & & $\sqrt{ }$ & $\sqrt{ }$ \\
\hline & Machine learning & & & $\sqrt{ }$ & $\sqrt{ }$ \\
\hline & $\begin{array}{l}\text { Principle and Application of } \\
\text { Intelligent Financial RPA }\end{array}$ & $\sqrt{ }$ & $\sqrt{ }$ & $\sqrt{ }$ & $\sqrt{ }$ \\
\hline & $\begin{array}{l}\text { Topic of intelligent counting } \\
\text { application }\end{array}$ & $\sqrt{ }$ & $\sqrt{ }$ & $\sqrt{ }$ & $\sqrt{ }$ \\
\hline \multirow{5}{*}{$\begin{array}{l}\text { Professio } \\
\text { nal } \\
\text { internshi } \\
\text { p } \\
\text { practice } \\
\text { link }\end{array}$} & $\begin{array}{l}\text { Enterprise ERP comprehensive } \\
\text { experiment }\end{array}$ & $\sqrt{ }$ & $\sqrt{ }$ & $\sqrt{ }$ & $\sqrt{ }$ \\
\hline & $\begin{array}{l}\text { Multi-organization business } \\
\text { simulation }\end{array}$ & $\sqrt{ }$ & $\sqrt{ }$ & $\sqrt{ }$ & $\sqrt{ }$ \\
\hline & $\begin{array}{l}\text { Virtual simulation experiment for } \\
\text { accounting major }\end{array}$ & $\sqrt{ }$ & $\sqrt{ }$ & $\sqrt{ }$ & $\sqrt{ }$ \\
\hline & $\begin{array}{l}\text { Comprehensive Experiment of } \\
\text { Accounting }\end{array}$ & $\sqrt{ }$ & $\sqrt{ }$ & $\sqrt{ }$ & $\sqrt{ }$ \\
\hline & $\begin{array}{l}\text { Visual oil and gas accounting big } \\
\text { data analysis and decision-making }\end{array}$ & $\sqrt{ }$ & $\sqrt{ }$ & $\sqrt{ }$ & $\sqrt{ }$ \\
\hline
\end{tabular}

\subsection{Build An Integrated High-level Teacher Team with Interdisciplinary Backgrounds}

The training of the faculty team will adhere to the principles of accounting theory, which is guided by interdisciplinary scientific research and digital intelligence technology so as to build an intelligent counting teaching and research environment and form a teaching-promoting research, research-based teaching and teaching-research collaboration. Driven by teaching 
goals and following the path of integration of scientific research and teaching, integration of development and innovation, a high-level team of teachers with a blend of academic background, theory and practice, and business and ability can be built.

\subsection{Build A Virtual Teaching Platform for Visual Oil and Gas Accounting Big Data Analysis and Decision-making}

The practical needs of the digital transformation of accounting in the oil and gas industry should be focused on, which relies on oilfield companies, oil data centers, technology companies and other companies to collaboratively build a virtual teaching platform for accounting professionals with characteristics of the oil and gas industry, with visualization as intelligent technology and big data analysis as the method. Under the virtual simulation environment of oil and gas business processes, the platform uses accounting standards as the framework to comprehensively train students to integrate professional skills with digital intelligence technology. At the same time, the platform can also provide oil and gas companies with high-quality visual accounting large databases, oil and gas economics and management scientific research database and research tool library.

\section{CONCLUSIONS}

This paper takes the transformation of the digital intelligence era as the research perspective and logical entry point, and systematically explores the construction path, construction mode and construction method of the higher accounting applied talents innovation training system. Based on the interdisciplinary background, and the construction of virtual simulation teaching platform, three horizontal (accounting, oil and gas business, digital intelligence technology), three vertical (theoretical teaching, practical simulation, internship and practice), four-dimensional (accounting professional judgment ability, oil and gas enterprise industry and financial integration ability, digital intelligence technology application ability, discipline integration thinking ability), four integrated teaching mode (enterprise, public institution, scientific research institute and accounting professional organization) are constructed. It can provide useful enlightenment and reference for the transformation and construction of accounting majors in other colleges and universities.

\section{REFERENCES}

[1] D. Tang, B. Wang, Y. Liu, Reconstruction of Accounting Education in the Era of "Digital Intelligence”: Contradiction between Supply and Demand and Innovation of Elements, Accounting Research, 12 (2020) 180-182.
[2] Ministry of Finance, Notice on Issuing the "Outline of the 13th Five-Year Plan for Accounting Reform and Development”, [EB/OL].2016-10-8. http://kjs.mof.gov.cn/zhengcefabu/201610/t201610 18_2437976.htm.

[3] T. Wang, R. Cuthbertson, eight issues on audit data analytics we would like researched, Journal of Information Systems, 29(1) (2015) 155-162. DOI:10.2308/isys-50955

[4] K. Watty, J. McKay, L. Ngo, Innovators, or Inhibitors? Accounting Faculty Resistance to New Educational Technologies in Higher Education, Journal of Accounting Education, 36(9) (2016) 115. DOI: 10.1016/j.jaccedu.2016.03.003

[5] Y. Kuang, Y. Liu, Reform and Innovation of Higher Accounting Education in the Era of Artificial Intelligence, Research on Financial Issues, 7(2019) 96-103. DOI: 10.19654/j.cnki.cjwtyj.2019.07.012

[6] National Development and Reform Commission, Ministry of Education, Ministry of Finance, Notice on Issuing the National Pilot Implementation Plan for the Integration of Production and Education, [EB/OL ] .2019-1011.http://www.mof.gov.cn/zhengwuxinxi/caizheng xinwen/201910/t20191011_3399248.htm

[7] D. Sledgianowski, M. Gomaa, C. Tan, Toward integration of Big Data, technology and information systems competencies into the accounting curriculum, Journal of Accounting Education, 38 (2017) 81-93. DOI: 10.1016/j.jaccedu.2016.12.008

[8] S. Zhou, D. Tang, The Transition and Development of Accounting Education in the Intelligent Era, Accounting Research, 12(2019) 92-94.

[9] J. Zhou, J. Xu, X. Wu, Analysis on the Reconstruction of Accounting Course System under the Background of "Big Intelligence Moving Cloud" and Integration of Industry and Education, Business Accounting, 7 (2020) 115-118.

[10] J. Wei, C. Gu, Research on the Reform of Undergraduate Accounting Interdisciplinary Education in the Age of Digital Intelligence, Business Accounting, 8 (2021) 115-116. 